\title{
The "Crime Passionnel" in French Courts
}

I. Introduction and the LAw.

MERICANS have heard a great deal about the crime
passionnel. They have heard more about it as a French
phenomenon than as an American one passion, so-called, crimes through jealousy, happen very often in America, although not so often as in some European countries. But we do not speak so freely and frankly concerning them. In several parts of the United States, and even in a large, presumably civilized city like the City of New York, we have acquittals in the case of crimes through passion. But we, in America, especially the people of the East, have a wrong conception concerning the treatment in France of individuals who have committed such crimes. We get our impression from the sensational cases that happen in Paris. The two elements that I wish to emphasize in the preceding sentence are "sensational" and "Paris." The ordinary trials go on unnoticed there, even ordinary trials of prisoners who have committed crimes of jealousy. It is only the trial with more than the average human interest and with fascinating personalities which attracts the reporters, and which is spread out before the readers. Furthermore, we in America have not been treated justly by our correspondents. We have been made well acquainted with what has happened in Paris, but not with what has happened in the provinces.

The treatment accorded to persons who commit crimes of passion in Paris is entirely different from the treatment accorded to such persons in the provinces. In Paris there is an acquittal in almost every case. I do not know of a single case, from personal experience, and also from conversation with other people, in which the man who has been betrayed, as we say, by his wife or his mistress, and has killed her, has been convicted. But the attitude of the jury is entirely different when a woman appears before the bar of justice, except in the rare case, such as that immediately previous to the war-the Caillaux Case. In the provinces, however, there is no distinction made between men and women, and furthermore, there is no distinction made between crimes of passion and crimes of other sorts. Our American pro- 
cedure is the same as the Paris procedure so far as acquittal is concerned, but different in that the Parisians acquit the man and convict the woman, and we acquit the woman and convict the man. Extenuating circumstances may be invoked, but these circumstances are invoked in every other case and are applied in every case by the jury. The provincial jury also applies the extenuating circumstances in cases of crimes of passion, but very rarely, if ever, do the extenuating circumstances influence the jury to the extent of producing an acquittal.

Paris in wartime is not a good place to see the trial of a case for the commission of the crime passionnel. There are certain special circumstances which come before the jury in this time of stress and strain, which make the verdict of acquittal of the jury more easy to understand than in peace time. The Parisian juxy is to be reproached for the ease and nonchalance with which it emits acquittals in cases of crimes of passion. Sometimes the extenuating circumstances are great, sometimes the extenuating circumstances are small; but in all cases, great or small, the operation of the jury in peace time constantly violates the law.

In America you almost never have a defendant who, in a crime of this sort, admits his or her guilt. If there is an admission of the commission of the crime, the defense of insanity is set up, especially the defense of temporary insanity, in order that the defendant may escape the insane asylum. If an admission of guilt were made, the case would be taken from the jury. But in France, the jury being judge of the act charged as a crime, and also of the question whether there are any extenuating circumstances in the case, the case goes on even after an admission of the crime. Everything in the life of the prisoner which can be brought out and which will tend to minimize the crime he has committed, will be brought out. Further, the juxy is the judge both of the facts and of the law, and therefore decides whether the defendant is guilty of murder. But the trial itself is not a full and complete trial. It does not bring out all the evidence in the case. Before the case comes to the court with a jury, there has already been a thorough investigation made by a magistrate. This magistrate is called the juge d'instruction. It usually takes him a long time to complete this investigation, because the inethods in use in the office of the juge d'instruction are old and antiquated. Witnesses for both sides come before him and are examined by him. There is no cross-examination to speak of, except of the 
defendant. The witnesses tell their stories to this magistrate. The magistrate frames questions, and the clerk writes the questions down. The magistrate, after communication with the witnesses, also frames the answers, which the clerk writes down. But all this writing is done in longhand. Sometimes it takes several hours to examine one witness, whereas in America the statement of that witness would be taken in fifteen minutes. Evidence of all sorts is taken. Evidence of witnesses who can testify to the actual facts of the crime; evidence of witnesses who can testify to the character of the defendant; evidence of witnesses who can testify to what they know only by hearsay. All the evidence gathered by this judge is put in what is called a dossier. That is the book, written out in longhand, that goes up to the three judges in the Cour d'Assises which is the court with a jury which tries cases of felony.

The president of the tribunal is informed, before he comes to court, of everything in the dossier. He has made a complete study of the case, and has taken notes. The attorney for the defendant and the prosecuting attorney, also know the facts of the case. Under our procedure, the prosecuting attorney is the person who presents the case, and who begins by making an exposition of the case to the jury; but under the French system, the president of the court is the one who makes this exposition and presentation. The presentation is seldom by narration. It is nearly always by means of question and answer; the questions being put to the defendant and other witnesses. There is no formal narration of the whole case presented to the jury as in our American procedure, and then evidence adduced in support of that narration. The jury has to make the most of the case as it goes along; but the peculiar procedure in the French courts does allow the jury to get, at the end of the questioning of the defendant, a fairly good idea of the whole case. The defendant answers the question of the president usually fully and freely, and it is due to this fact-to the utter frankness of the defendant and his willingness to talk-that the jury are put in possession of the facts almost immediately.

The defendant, under our procedure, may not be questioned. But in France, and on the continent generally, one of the great instruments in the detection and suppression of crine is the power of questioning an accused person. We Americans are tender of the rights of the defendant, and are neglectful of the rights of 
society. We are constantly told that the whole social and legal structure in America will fall if we change the law in regard to a defendant's testimony. Our Constitution prohibits a man's giving evidence against himself. If we do not change our Constitution, we ought to change our law to this extent: Let the jury draw inferences against a defendant if the defendant does not take the stand in his own behalf. It would not he very long before every defendant testified. The effect upon the jury of a person who did not take the stand and explain the case against him would be so dangerous for the interests of the defendant, that the defendant would very likely follow the only wise course open to him-frank and full disclosure.

\section{The Man in the Case.}

I attended last year in Paris an exciting trial for a crime passionnel. The defendant was a man of about forty-five, a soldier who had been in all the great campaigns since the beginning of the war. He was at the Battle of the Marne, in Champagne, at Verdun and in the Somme. His history for the last two and a half years had been a history of continued and valiant fighting. He had been several times decorated for bravery, and his superior officer spoke of him as a man of high intelligence, of sobriety and poise. He loved his wife and his children, but the beginning of the war saw him torn away from his fireside. $\mathrm{He}$ went willingly, however, because he thought he was defending his hearth. But after a while, letters from his parents and from his friends began to come to him, which directed his suspicion to his wife. He had seven children, and during his absence at the front his wife had put them all in charity homes. He heard his wife had a lover. People had followed her and had seen her enter hotels with this man; and, indeed, she had been telling people that she did not love her husband, did not care what happened to him at the front, wished him killed, the sooner the better, because that would leave her free to continue in the embraces of her lover.

One day, the soldier came back on furlough. He had seven days, but he told his wife that he had only two. At the end of the second day, he went off, presumably to the front, but really to get shaved and to transform himself into a civilian. $\mathrm{He}$ followed his wife, and he saw her do exactly the things people had been telling him she did. There was a terrific scene, in which 
the coldness and the indifference of the woman were in striking contrast with the softness and the love of the man. He begged her to give up this man; he told her that he would pardon her for all she had done. She was unrelenting. He pleaded with her in the name and for the sake of their children, but she was marble.

He left. He went to the Palais de Justice-the law courts of Paris. Since the beginning of the war there has been in operation in the Palais de Justice, in the office of the battonnier (who is the president of the order of barristers of Paris), a sort of legal aid society. The society is simply for consultation; it does not go as far as the legal aid societies of our cities go. Although this soldier had taken life so easily at the front, he found it hard to take the life of the woman he loved. He consulted an attorney at the office of the bâtonnier. As the wife's relentlessness made reconciliation impossible he sought a divorce. If this woman continued to be his wife, she would receive a pension; a divorce would make the children beneficiaries. The difficulties in the way of getting a divorce were explained by the attorney at the office, and they loomed large in the eyes of this soldier. $\mathrm{He}$ was told that it would probably be a year or a year and a half before he could get his divorce, that there were a great many obstacles along the way, and that it was not certain whether he would get it; that there were all sorts of evidence to be produced; that there were all sorts of intricate mazes to be traversed. What could this man do? He said: "Do I have to wait so long? Suppose I am killed tomorrow, what will happen to the pension? My children will be starving in the streets. Is it possible that I can get no justice unless I take the law into my own hands?" This man of iron, who had stood all the horrors of war and all its terrors, was now meek and subdued. Before he left the office, he got information as to how to proceed to put in an application for judicial assistance (which is legal aid for those persons who wish help in civil cases) to bring an action for divorce.

He set out for the front. Letters continued to come, one of which was from the authorities in charge of his application to bring the divorce action, notifying him that his application had been rejected because of insufficient evidence. He had many letters, the evidence was perfectly plain to him; he had seen it with his own eyes; there were a great many other witnesses who had seen it. 
He could not understand why he, a soldier of France, should be denied justice in a civil court.

He abandoned his regiment. Technically, this was desertion. He never dreamed of killing her, he had come simply for an explanation, for a last desperate attempt to convince her of the wrongness of her ways. Now that he could not get his divorce, the only thing he could do was to submit to the law and to make the best of this desperate situation, try to bring the mother back to a natural love for her children, whom he adored, and try to restore the love which he believed she had had for him. He loved his home and found comfort only there.

There was another scene, in which no reconciliation seemed to be possible. But he said: "I am a deserter, and for your sake. I have come here only through you. Will you not at least do this for me? Come with me to the bureau and say that I have come here because of the stories that have been running about concerning you. Admit the fact that you have not been faithful to me, and my superior officers will take the matter into consideration im the punishment that will be meted out to me." She responded: "You ask me a favor, and I shall ask one of you. If I come, will you destroy all those letters you have?" He said, "of course I will." "But destroy them first, before we go." They walked to the fire. He drew out a bundle of letters-the only evidence in writing he had of her unfaithfulness-and threw them into the fire. When they had all burned, she emitted unearthly laughter. "Aha!" she exclaimed. "Now I've got you. I don't love you, I don't care what happens to you. I won't go to the bureau with you. You have burned the letters . . . I go to iny lover."

The fumes mounted to his brain. He could no longer see, he could no longer think. He put his hand out to her, he took hold of her neck. Her neck was wrapped around with a shawl. $\mathrm{He}$ pressed the fingers. Before he knew it, the wife had collapsed.

He had no intention to kill. It was the furthest thing from his thoughts. His whole history had shown that this was a special case, entirely different from the ordinary case of the crime of passion. I once heard the president of the Cour d'Assises say that he could not understand how it was that these people who so much loved their victims, could kill them. Here was an individual who did not kill because he loved. He did not wish to kill. The death was simply by accident. He gave the impression to 
the jury of being a perfectly honest man. Even if his bearing before the jury had not been what it was; the simple recital of his history would have shown that he was not the kind of person to kill the object he loved. He was the kind to cherish it, and he cherished it until the very last moment, when confusion completely took possession of his mind. And even then he did not draw a knife or revolver. He simply threw out his hands and shut them, as he thought, very lightly. The most remarkable thing in the whole history is the softness, the tenderness, and the lack of impulsiveness on the part of this individual, who had been for two years and a half in the midst of the most terrific fighting, and who had seen and suffered everything a human being can see and suffer.

This was an excellent case for the jury to operate upon. The president was tender in his questioning, and the avocat-general, namely, the prosecuting attorney, was half-hearted in his prosecution. In France an accused person is indicted by a Chamber of Accusation, which is made up of seven judges. The dossier of the case goes up from the juge d'instruction to the Chamber of Accusations, and this decides whether the facts related in the dossier constitute a crime. The Chamber sends the case to the trial court for felonies-the Cour d'Assises. Once there, the judges have no power to dismiss the prosecution or direct an acquittal. The jury is judge of the law and the facts. The whole case must go before the jury whether the district attorney believes in the guilt of the defendant or not. The avocat-general was lenient, suggesting mercy to the jury. He indicated some of the extenuating circumstances in the case, and said that, while he felt this was a very good imstance for the application of extenuating circumstances, at least some punishment should be meted out to this man, who had at least committed manslaughter. The summing-up by the defendant's attorney was a masterpiece of narration and description. It was constantly punctuated by the applause of the audience. Sometimes the president of the court told the audience to keep quiet, sometimes he allowed the applause to pass without comment. It was a clear case for mercy. When the attorney concluded, the crowd was applauding and shouting. The jury was out only a few minutes, and came back with a verdict of "not guilty." 


\section{The Woman IN tHe Case.}

I now proceed to give a typical case with a woman as a defendant in order to show the difference in treatment by the jury.

The woman's appearance recalled the appearance of a woman who was at the same bar immediately before the beginning of the war. All France, and all the world in fact, had their eyes riveted upon that trial, which lasted for about a week. I read the stenographic report, and I have seen the woman. The woman in the case I am now describing looked like Madame Caillaux as she stood at the same bar nearly three years before. The defendant had been a servant in the house of the victim. The wife of the victim had been ill, and this servant in the house had been as a mother to the children of the sick woman. The story of the defendant was that, a little while before the death of the wife, the latter had called the servant to her, and had said: "I have but a short time to live. When I am dead, I hope you will continue to be the mother that you have been to my children." Even before the death of the wife, the servant in the house had become the mistress of the victim. After the wife's death, the servant and the victim lived together as man and wife. Witnesses testified to the fact that the household was well-conducted, and that there was perfect peace. The whole world, of course, knew that the two were not married, but that made no difference, because the woman was such a good mother to the children. The children were all small, and for six or seven years this mistress kept on acting the part of a wife, and the part of a mother. She had given her all, and she was constantly giving the very best of her life to the man and to the children. The latter idolized her and considered her as a mother. The master always found objections to marriage, and the unwedded state continued against the ardent desires of the mistress.

But times changed, and although the household had been a peaceful one for such a long time, and although this woman had made the man with whom she was living very happy, he began to find pleasure elsewhere, with women of the streets. Stories concerning his affection for one of them reached her. She followed him, and one day she entered the cafe where he and his companion were. She turned to the woman and said: "This is my husband." And then, turning to the husband, she said, "come home." This was too much for the pride of this 
representative of the male sex, and he determined that her days with him were numbered. He told her that she must leave at four o'clock in the morning; that if she had not left by that time, he would throw her out of the house; that she was never to return again, and that henceforward he disowned her completely and abandoned her. The future was a complete blank to her. She loved very much, and at the time of the trial and her examination and cross-examination by the president of the court, she talked and talked long, reiterating how much she had loved him, and that she did not know why it was that she had killed him. She called upon God, in the most dramatic fashion, and she called upon the witnesses present to testify how much she adored him. The children of the dead man came to testify to the motherly treatment they had always received. Her narration, which lasted for over an hour and which held the whole court room spellbound, revealed a case of intricate psychology. It was because she had loved, and loved so much, that she had killed. But the president was skeptical and he was wondering whether some other object had not induced her to murder; whether it was not because she was being left alone to shift for herself; because her support had failed her. She reiterated that she did not think of these things at all; that the only thing she thought of was the fact that the object she loved was being completely lost to her.

At five o'clock in the morning she was still at home, in the room the master had ordered her to leave. The victim awoke. He turned to her: "Are you still there? If you don't get out I'll throw you out of the window." The man fell asleep again. The woman considered. There was a revolver lying upon the table-his revolver. She stretched forth her hand and fired once. And then she came to herself. She presented herself to the Commissaire de Police, and said: "I have just killed the man I loved."

The story was a thrilling one. Yet, in the case of a man, the extenuating circumstances existing in the case of this woman would have been sufficient for the jury to acquit. But because the jury arrogates to itself the presumption of saying that a man has the perfect right to kill the woman who has betrayed him, but that a woman has not the right to kill the man who has betrayed her, it convicted. She received the benefit of exten- 
uating circumstances and was sent to prison at hard labor for twenty years.

IV. History of the Jury's Attitude in Cases of the Crime PASSTONNEL.

The attitude of the Paris jury has a short history. Forty years ago, juries in Paris acted as juries in the provinces did in cases of crimes of passion. But a little over a generation ago, Alexandre Dumas, the younger, published a pamphlet called "Tue-la." It was vacation time, and people, especially journalists, were anxious to have something to talk about. The pamphlet created a great stir in newspaper offices. The newspapers discussed the question raised by the pamphlet, pro and con, and the readers of the papers were invited to express their opinions,and they expressed them. "Has the man, husband or lover, who has been deceived, the right to kill the woman who has proved unfaithful?" When the discussion was at its height, a case of the crime passionnel presented itself. Everybody was concerned as to how the jury in the case would treat the matter. The previous treatment was not sufficient. It no longer held valid. At least, if it was not invalid, it was tottering. Alexandre Dumas and the newspapers had given it a blow. Whether the oldfashioned treatment by the jury had suffered was yet to be seen. All the newspapers were represented at the trial. It was a gala occasion. Alexandre Dumas himself, followed by a train of attendants and admirers, appeared upon the scene, in all the glory of his previous and potential success. The president of the tribunal was infected by the spirit of the time. He was a man of artistic taste, and his questioning of the defendant was a masterpiece of art. There were three centers of attraction in the court rooin: One was the president, the other was the defendant and the third was Alexandre Dumas himself. Dumas was confident of a victory. He had nuaintained the justice of murder in the circumstances. He had struggled hard in the pamphlet and in subsequent discussion to prove that the only logical, inevitable and just thing for a man to do who had been betrayed by his wife or his mistress, was to kill her.

The outcoine of the trial was a complete triumph for his ideas. The jury, in complete reversal of the actions of juries in the past in similar cases, acquitted the defendant. The result 
had a tremendous repercussion. It was the first acquittal of the sort, to which can be traced the subsequent continuous history of acquittals in cases of crimes of passion. The story of the origin of these acquittals as I have given it, was told me by a distinguished professor, who was himself present at the trial.

Alexandre Dumas subsequently published "L'Affaire Clémenceau." The book is the speech in court, of the attorney of a defendant who has been betrayed. Every conceivable argument, every conceivable appeal to passion that can be invented, is invented by Alexandre Dumas and put into the mouth of the lawyer in the book. The work created a great sensation. It confirmed and strengthened the action the jury had taken, and it was the source of a flood of novels of the same character. For thirty years France has been deluged with the type of play and novel in which the crime of passion is discussed, and with which the world is familiar. The "Affaire Clemenceau" was dramatized by D'Artois, and in the form of a play the sentiments of the pamphlet and of the novel were made more popular and more vivid. If anyone wishes to know a little of the sources of the salacious literature for which the French have been so much condemned for the last thirty years by the world that was ignorant of the real literature of France, he must go back to the books I have mentioned. Intelligent Frenchmen abommate this literature, and abominate the sentiments and the actions to which it leads.

New York City.

Robert Ferrari. 